Article

\title{
A Strategy for International Cooperation in the COVID-19 Pandemic Era: Focusing on National Scientific Funding Data
}

\author{
Doyeon Lee ${ }^{1}$, Yoseob Heo ${ }^{2}$ and Keunhwan Kim ${ }^{1, *}$ \\ 1 Division of Data Analysis, Korea Institute of Science and Technology Information (KISTI), \\ Seoul 02456, Korea; dylee@kisti.re.kr \\ 2 Busan Branch, Division of Data Analysis, Korea Institute of Science and Technology Information (KISTI), \\ Busan 48058, Korea; joseph87@kisti.re.kr \\ * Correspondence: khkim75@kisti.re.kr; Tel.: +82-2-3299-6072
}

Received: 17 June 2020; Accepted: 7 July 2020; Published: 9 July 2020

\begin{abstract}
The coronavirus crisis may lead to a deeper understanding of international collaborations for developing antivirals and vaccines that are essential to protect us from current and future health security threats. Beyond technical solutions, the government of South Korea needs to establish a timely strategic investment in coronavirus-related research and development (R\&D) in order to enhance the capabilities for managing this new uncertainty in regard to the domestic health crisis. Thus, this study aims to provide useful information about the status of global coronavirus-related research from the South Korean government's perspective. National funded projects stemmed from leading nations such as the United States, countries of the European Union, and Japan between 2012 and 2018. Six research fields were derived by clustering analysis and an expert-based approach, and then matched to those of South Korea. The comparative analysis among them allowed for the identification of the nations' strengths and weaknesses, thereby laying the groundwork for strategic international research collaborations.
\end{abstract}

Keywords: coronavirus; international cooperation; national scientific funds; cluster analysis; pandemic; health policy

\section{Introduction}

The third zoonotic human coronavirus of the century emerged in December 2019, with a cluster of patients with connections to Huanan South China Seafood Market in Wuhan, Hubei Province, China [1,2]. The cases of those infected in China had spread to the US, Thailand, Japan, and South Korea (hereafter Korea) on a smaller scale by early February. The confirmed cases in other countries increased [3], and a global pandemic of COVID-19 caused by severe acute respiratory syndrome coronavirus 2 (SARS-CoV-2) was eventually declared by the World Health Organization on 11 March 2020 [4].

The world has already learned the importance of working collaboratively to overcome two global outbreaks, which stemmed from the SARS outbreak of 2002 and the MERS outbreak of 2012. After the SARS outbreak in 2003, it took researchers about 20 months to develop a vaccine for human trials. In 2015, researchers were able to prepare a vaccine for the Zika virus in just six months [5].

As the world is increasingly interconnected and the COVID-19 epidemic continues [6], it is of the utmost importance for both the developed and developing nations to facilitate international cooperation and to protect the health of the world's population [7-9]. At the center of the WHO, its networks of researchers and other experts have coordinated global work on surveillance, epidemiology, modeling, 
diagnostics, clinical care and treatment, and on researching other ways to identify and manage the disease and limit its onward transmission [5,9], thereby reducing the probability of the high lethality of viruses such as SARS-CoV, MERS-CoV, H5N1, H7N9, and Ebola [10]. In order to contribute to the treatment and prevention of the virus with the collaborative efforts of countries around the world, much research will continue to be conducted in the fields of pathogen monitoring, source identification, primary etiology, clinical treatments, vaccine development, viral replication, pathogenesis, antiviral drugs, and others [9-11]. The US CDC, as well as other national governmental bodies, has the explicit goal of preventing sustained outbreaks like COVID-19 within their borders but also makes significant contributions to ongoing publicly shared research in disease transmission, diagnostics, vaccine development, and therapeutics, as well as offering guidelines to front-line clinicians and coordinating with both the WHO and local health departments [12].

Although the world is already preparing to tackle the newest emergent virus strain [1], vaccine research and development are highly complex and require concerted public funding efforts for a long period of time $[8,13]$. In order to improve the efficiency of the allocation of the funding for infectious disease-related $R \& D$, it is necessary to understand the current trends of coronavirus disease-related scientific research funding around the world to consider the directions for the global collaborative research and development $[14,15]$.

It was first reported that a patient in Korea was infected with COVID-19 on 20 January 2020 in Korea (ncov.hohw.go.kr); community-based spread dramatically occurred in Korea [16], thereby positioning it as one of the first countries to have an outbreak beside China, based on reported laboratory-confirmed COVID-19 cases. As of 6 March 2020, 17,481 cases of COVID-19 had been confirmed outside China, 6284 of which were confined to South Korea (42 deaths). Italy (3858 confirmed cases and 148 deaths) and Iran (3513 confirmed cases and 107 deaths) were ranked next (WHO 2020 Situation Report-46) [3].

The Korean government and its other agencies, such as the Korea Center for Disease Control (KCDC), have made saving lives their highest priority by implementing comprehensive testing and tracking, which allowed for the early detection, isolation, and treatment of patients while minimizing widespread mobility restrictions. As a result of the cooperation between government agencies and the wider public, the number of confirmed cases slowed down to an average of less than 10 per day in May, compared with more than 500 new cases per day in late February and early March. During the COVID-19 crisis, the Korean government's rapid response to the epidemic resulted in the substantial improvement of the national scientific research ability and research equipment through the integration of scientific research resources, increase in research investment, strengthening of direct cooperation between international and domestic scientists, and acceleration of the clinical applications of scientific research results [17], thereby enhancing the ability to prevent the spread of the epidemic or accelerate the elimination of the virus [18]. The Korean government was able to pause and reflect after the peak of the coronavirus crisis started to subside.

Due to the magnitude of the public funds invested in infectious disease-related research [14], the Korean government has to evaluate their investment strategy about which research fields must be invested in and in which research fields is needed collaboration with international partners to reach important research goals [13]. To date, few studies have provided a comprehensive analysis of infectious disease R\&D from a public funding perspective [13-15]. To the best of our knowledge, there is no study to satisfy both prerequisites for understanding what coronavirus disease-related research and development has been conducted from both the world's and South Korea's perspectives. Therefore, this study aims to provide useful information about the coronavirus disease-related scientific research trends of leading nations and Korea during the 2012-2018 time period and then analyze this research to plan further scientific research. Many studies have indicated that the US, EU, and Japan have critical roles in the scientific and technological advancements in infectious diseases $[14,19,20]$. In particular, as the four leading national scientific funding organizations or programs related to the health domain in the world, the National Institutes of Health (NIH) of the US; the framework programs for research and innovation (i.e., Horizon 2020) funded by the EU; and the Grants-in-Aid 
for Scientific Research (KAKENHI) program of the Ministry of Education, Science and Culture of the Japanese government are significant [21,22]. Therefore, the data from government-funded projects were gathered from searchable, open, project-based information databases such as STAR METRICS, CORDIS (Community Research \& Development Information Service, Brussels, Belgium), and KAKEN (Database of Grants-in-Aid for Scientific Research, Shizuoka, Japan), respectively, that are available for individual or multiple institutions in those places. Besides, the official centralized national R\&D database called the National Science \& Technology Information Service (NTIS) — which has gathered, managed, and provided all Korean government-funded research information since 2004 (www.ntis.go.kr)—was utilized. This paper aims to apply machine learning methodologies and network analysis to understand how the US, EU, and Japan have invested their funding to determine what coronavirus disease-related research fields already exist and match those to the Korean projects with designated research fields stemming from leading nations' data analysis. Our research addresses the following questions:

1. What coronavirus-related research has been conducted amongst leading nations since 2012?

2. What coronavirus-related $R \& D$ fields has Korea invested in since 2012?

3. What differences exist amongst coronavirus-related R\&D fields?

4. What insights into coronavirus-related R\&D fields has Korea gained in order to prepare for the post-COVID-19 pandemic?

The remainder of this paper consists of four sections. Following this general introduction, the "materials and methods" section describes the framework and methodology. The "results" section presents comparative results of the research profiling and machine learning analyses. The "conclusion and discussion" section reviews our research, identifies the research limitations, and indicates promising research opportunities to pursue.

\section{Materials and Methods}

\subsection{Data Collection}

The data used in this study are national-funded $R \& D$ project information and were collected from the global R\&D database provided by STAR METRICS of the US, CORDIS of the EU, and KAKEN of Japan. The global R\&D database was built and is operated by the Korea Institute of Science and Technology Information (KISTI) internally, funded by the Ministry of Science and ICT of Korea. It has data from approximately 1 million nationally funded projects between 2012 and 2018. The detailed process of database establishment is described in [15]. The data from Korea were collected from NTIS, which is utilized in many studies of Korean R\&D trends [23-25]. A total of 599 and 638 nationally funded R\&D projects related to coronaviruses between 2012 and 2018 were collected from the developed nations (the US, EU countries, and Japan) and Korea with these query sets in Table 1, respectively.

\subsection{Data Pre-Processing for Further Analysis}

None of the national R\&D databases provide the complete information of all nationally funded projects. For example, suppose that a five-year nationally funded scientific project was started in June 2015. STAR-METRICS and NTIS contained funding information for some fiscal years, which did not allow us to estimate the total amount of funds for multi-year projects. Thus, calculations were estimated by multiplying the average funding amount per year that was extrapolated based on the title of these projects in the global R\&D database and the total period (year) of these projects. After that, we removed some data that included the number of funded projects that were zero and kept some data by adding the organization names as found through manual searches for these projects from other data sources. Table 1 shows a total of 273 and 170 nationally funded R\&D projects related to coronaviruses utilized for further analysis, respectively. 
Table 1. The source of global R\&D project data.

\begin{tabular}{|c|c|c|c|c|}
\hline $\begin{array}{c}\text { Geographic } \\
\text { Region }\end{array}$ & Data Source & Search Terms & $\begin{array}{l}\text { Number of } \\
\text { Raw Data }\end{array}$ & $\begin{array}{l}\text { Number of } \\
\text { Utilized Data }\end{array}$ \\
\hline $\begin{array}{l}\text { USA- } \\
\text { STAR-METRICS } \\
\text { EU-CORDIS } \\
\text { Japan-KAKEN }\end{array}$ & Global R\&D database & $\begin{array}{l}\left(\text { corona }^{*} \text { AND virus *) OR coronavirus * OR }\right. \\
\text { mers-cov * OR sars-cov * OR covid * OR "severe } \\
\text { acute respiratory syndrome" OR "middle east } \\
\text { respiratory syndrome") }\end{array}$ & $\begin{array}{l}554 \\
35 \\
10\end{array}$ & $\begin{array}{l}10 \\
35\end{array}$ \\
\hline \multirow[t]{2}{*}{ Korea } & NTIS & $\left(\right.$ corona $^{*} \mid$ sars ${ }^{*} \mid$ mers $\left.{ }^{*}\right)$ & 638 & 170 \\
\hline & & $\begin{array}{c}\text { Total } \\
\text { (Period: 2012-2018) }\end{array}$ & 1237 & 443 \\
\hline
\end{tabular}

Search terms marked with an asterisk ${ }^{*}$ ) are root or stem words, indicating that all possible suffixes are covered under the query.

\subsection{Clustering Through Co-Occurrence Matrix}

As a way of identifying coronavirus-related R\&D areas, the co-occurrence matrix was made in terms of the ASJC code (All Science Journal Classification Codes) of Scopus by using the Vantage Point ${ }^{\circledR}$ system (Search Technology, Inc., Norcross, GA, USA) as demonstrated in [15]. From the single standard's perspective, the ASJC code was previously assigned to all the projects in the global R\&D database that employed the machine learning approach to classify the different R\&D projects that stemmed from the US, the EU, and Japan [15]. The number of data utilized by Korea, which has the characteristics of the centralized database, was as high as that used by the US. It may cause a "home advantage" bias [26,27]. Thus, the data of Korea excluded the making of a co-occurrence matrix.

Identifying the association among ASJC codes through the co-occurrence matrix implied a network structure. Thus, the VOSViewer (Leiden University, Gravenhage, the Netherlands) software was used as a network structure visualization tool to understand the relationship between ASJC codes [15]. The VOSViewer system calculates the similarity between each component and visualizes the network structure in the form of a cluster map or a topographic map [28]. A mathematical model and algorithm of VOSviewer's clustering and mapping can be found in Van Eck and Waltman [29]. The software has been used in various studies to identify the research fields [30,31].

\subsection{Sub-Clustering and Definitions of (Sub-)Clusters}

The constructed clusters were initially subdivided into more detailed sub-clusters. Therefore, in order to derive more coronavirus-related $\mathrm{R} \& \mathrm{D}$ areas from more massive clusters, each larger cluster was divided into several sub-clusters. After that, the definitions of coronavirus-related R\&D areas were determined by directly and carefully reviewing $R \& D$ projects comprised of clusters or sub-clusters.

\subsection{Allocating All the Projects to (Sub-)Clusters}

The clustering techniques drop many data from the original data [15], which prevents us from comparing the amount of R\&D funding among the US, the EU, Japan, and Korea. Thus, all of the projects that were excluded from each (sub-)cluster were accorded with each (sub-)cluster or removed if they did not belong to any cluster according to experts. We sought to draw out the significant implications for the directions of the coronavirus-related R\&D planning of Korea through the comparisons between the nations. The whole process is shown in Figure 1. 
1. Data collection and retrieval from developed nations

- Keywords search: (corona* AND virus*) OR coronavirus* OR mers-cov* OR sars-cov* OR covid* OR "severe acute respiratory syndrome" OR "middle east respiratory syndrome"

- 599 national funded scientific projects

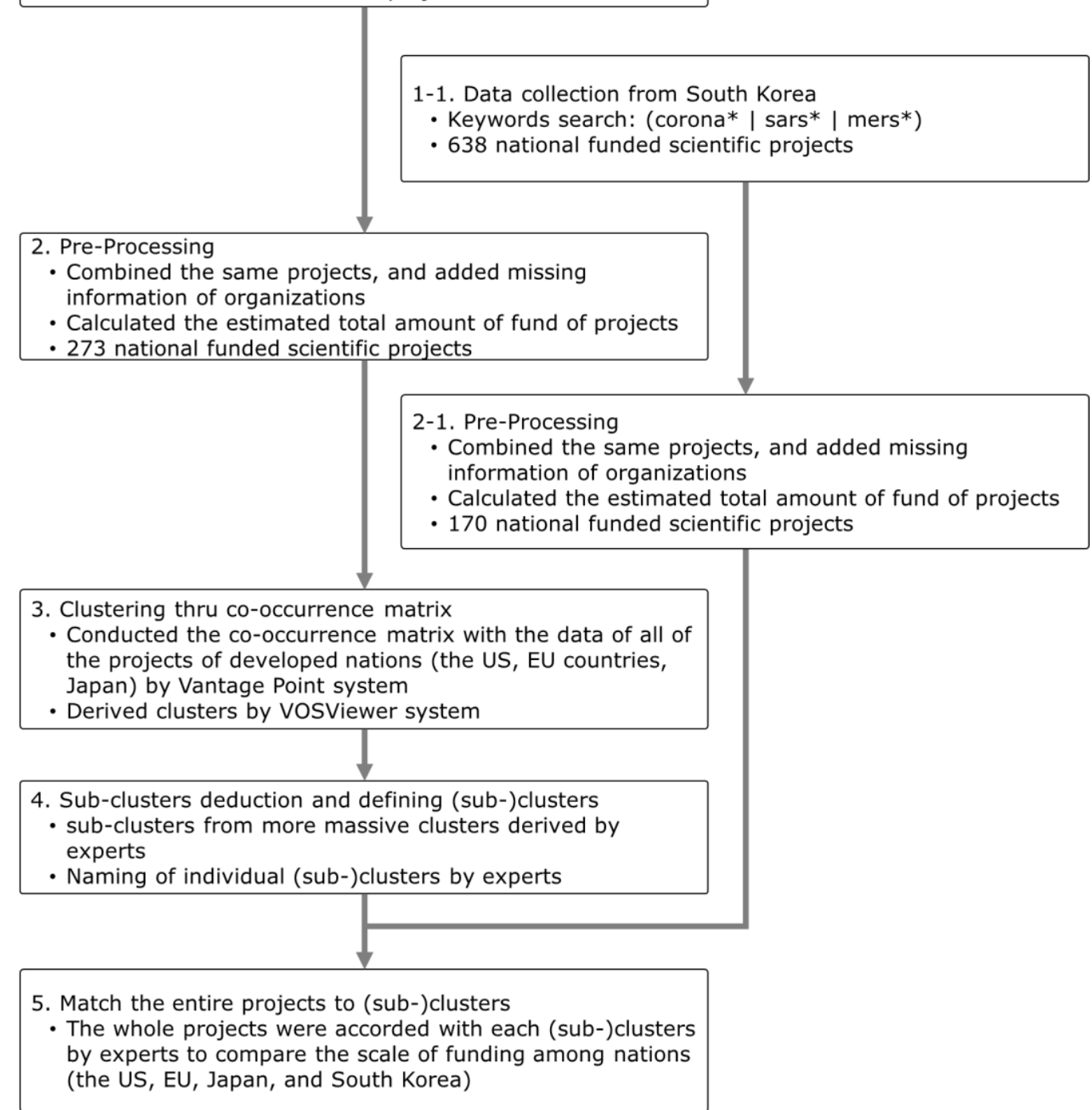

Figure 1. The workflow of the comparison of coronavirus-related R\&D areas among the US, the EU, Japan, and South Korea. Search terms marked with an asterisk $\left(^{*}\right)$ are root or stem words, indicating that all possible suffixes are covered under the query.

\section{Results}

3.1. Research and Development Fields of Coronavirus-Related National Funded Projects of the US, the EU, and Japan

As shown in Figure 2, the scientific research fields of the coronavirus-related national funded projects in the US, the EU, and Japan may be divided into three clusters (categories). After reviewing the research descriptions of the funded projects, distinct subjects in significant clusters such as Cluster 1 and 2 were deduced by experts and named to include the core meanings of the individual research fields as follows: (Cluster 1) research on the molecular characteristics of infectious viruses and the interaction mechanisms of viral pathogens and human hosts, including the immune response, for developing diagnostics, therapeutics, and a vaccine against COVID-19; (Sub-Cluster 1-1) research related to the mechanisms of infection, the life cycle of SARS-CoV-2, and the identification of a virus-host 
interaction mechanism; (Sub-Cluster 1-2) research related to the platform for the immunological response to viral infection and for vaccine development; (Sub-Cluster 1-3) the platform for detection and point-of-care diagnostics; (Cluster 2) research on the virus protein structure-active/function-based antivirus therapeutics (treatment) design and active/resistance modulation research on the virus protein structure-active/function-based antivirus therapeutics (treatment) design and active/resistance modulation; (Sub-Cluster 2-1) structure-activity relationship modeling-based virus prediction and activity modulation; (Sub-Cluster 2-2) studies on the design of antiviral agents based on the structure and function of viral and human receptor proteins; and (Cluster 3) infectious disease epidemiological investigation and animal and environmental ecology (all of the national funded projects in each (sub-)cluster are provided in the supplementary material). The next sub-sector describes the detailed investigation for each cluster.

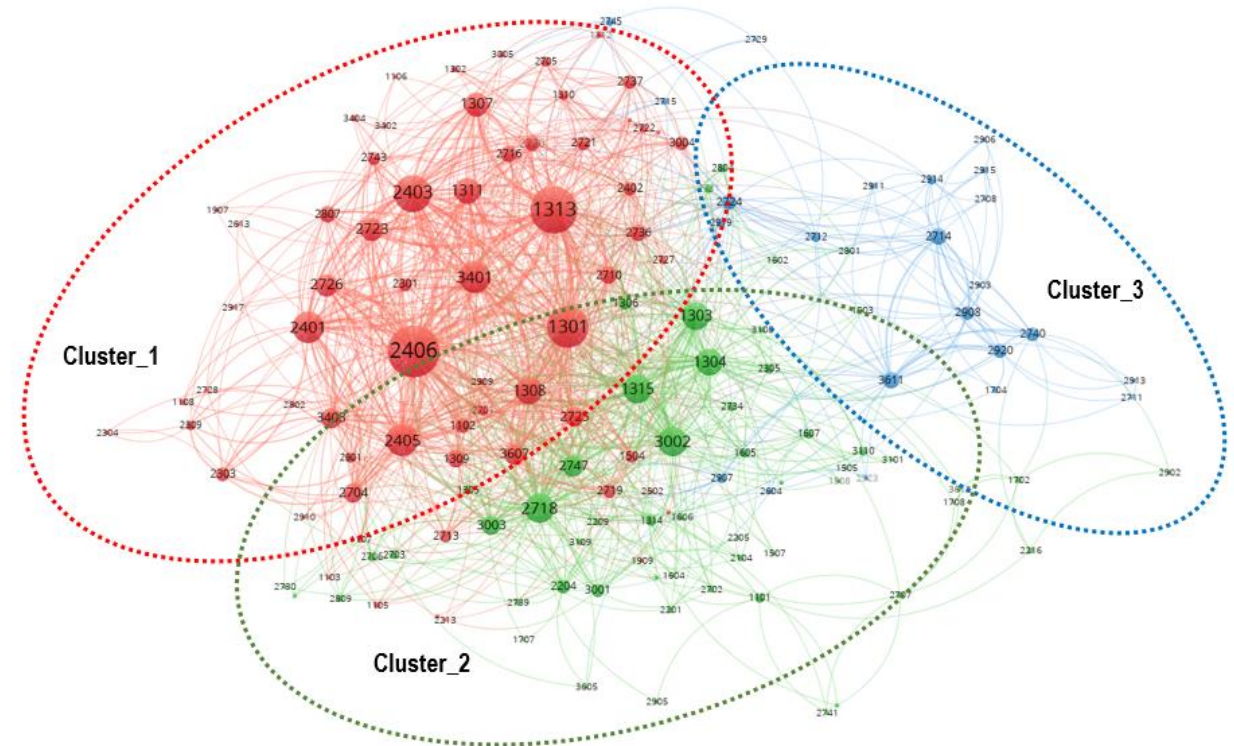

Figure 2. Clusters of R\&D fields on coronavirus-related national-funded projects of the US, the EU, and Japan.

3.1.1. Research on the Molecular Characteristics of Infectious Viruses and the Interaction Mechanism of Viral Pathogens and Human Hosts, Including the Immune Response, for Developing Diagnostics, Therapeutics, and a Vaccine against COVID-19 (Cluster 1)

Research on the molecular characteristics of infectious viruses and the interaction mechanism of viral pathogens and human hosts, including the immune response, for developing diagnostics, therapeutics, and a vaccine against COVID-19 (Cluster 1) were studied in 135 projects, which totaled 367,501,552 USD.

Firstly, research related to the mechanisms of infection, the life cycle of SARS-CoV-2, and the identification of a virus-host interaction mechanism (Sub-Cluster 1-1) in general consisted of 81 projects worth 186,810,747 USD. The University of Maryland in the US recently completed a project called "Host, pathogen, and the microbiome: determinants of infectious disease outcomes" and spent 19.6 million USD between 2014 and 2019. The University of Pittsburgh and the University of Iowa have participated in projects entitled "Targeting host responses to prevent virus induced ARDS in the nonhuman primate model" and "Role of eicosanoids in pathogenic human CoV infections", respectively. Meanwhile, Erasmus Universitair Medisch Centrum Rotterdam of the EU and Yamaguchi University of Japan conducted a project entitled "European management platform for emerging and reemerging infectious disease entities" with expenditures of 18.6 million USD between 2009 and 2014, and "Elucidation of the mutation mechanism and virulence acquisition machine of coronavirus" with a cost of 514,800 USD between 2015 and 2018, respectively (see Table 2). 
Table 2. Research related to the mechanisms of infection, the life cycle of SARS-CoV-2, and the identification of a virus-host interaction mechanism (Sub-Cluster 1-1).

\begin{tabular}{|c|c|c|c|c|c|c|c|}
\hline NO & Organization & Title & $\begin{array}{l}\text { Estimated Average } \\
\text { Cost/Fiscal Year } \\
\text { (USD) }\end{array}$ & $\begin{array}{l}\text { Estimated } \\
\text { Total Cost } \\
\text { (USD) }\end{array}$ & Start Date & End Date & $\begin{array}{l}\text { Geographic } \\
\text { Region }\end{array}$ \\
\hline 1 & $\begin{array}{c}\text { University of } \\
\text { Maryland Baltimore }\end{array}$ & $\begin{array}{l}\text { Host, pathogen, and the } \\
\text { microbiome: determinants of } \\
\text { infectious disease outcomes }\end{array}$ & $3,926,048$ & $19,630,240$ & 15 April 2014 & 31 March 2019 & US \\
\hline 2 & $\begin{array}{l}\text { The University of } \\
\text { Pittsburgh }\end{array}$ & $\begin{array}{l}\text { Targeting host responses to } \\
\text { prevent virus induced ARDS } \\
\text { in the nonhuman } \\
\text { primate model }\end{array}$ & $1,809,375$ & $1,809,375$ & 15 September 2018 & 14 September 2021 & US \\
\hline 3 & $\begin{array}{c}\text { The University } \\
\text { of Iowa }\end{array}$ & $\begin{array}{l}\text { Role of eicosanoids in } \\
\text { pathogenic human } \\
\text { CoV infections }\end{array}$ & 545,235 & $2,726,175$ & 23 September 2016 & 31 August 2021 & US \\
\hline 4 & $\begin{array}{l}\text { Erasmus Universitair } \\
\text { Medisch Centrum } \\
\text { Rotterdam }\end{array}$ & $\begin{array}{l}\text { European management } \\
\text { platform for emerging and } \\
\text { reemerging infectious } \\
\text { disease entities }\end{array}$ & $3,736,307$ & $18,681,536$ & 1 May 2009 & 30 April 2014 & EU \\
\hline 5 & Yamaguchi University & $\begin{array}{l}\text { Elucidation of the mutation } \\
\text { mechanism and virulence } \\
\text { acquisition machine } \\
\text { of coronavirus }\end{array}$ & 171,600 & 514,800 & 1 April 2015 & 31 March 2018 & JP \\
\hline
\end{tabular}

Secondly, research related to the platform for an immunological response to viral infection and vaccine development (Sub-Cluster 1-2) was comprised of 38 projects worth 146,167,160 USD. The University of North Carolina Chapel Hill in the US is projected to have spent 24 million USD on its "Systems immunogenetics of biodefense and emerging pathogens in the collaborative cross" by the time the 10 year project wraps up in 2022. The New York Blood Center committed to spending 4.5 million USD on a vaccine project titled "Structure-based design of coronavirus subunit vaccines" between 2018 and 2023. Meanwhile, The National Institute of Infectious Diseases of Japan finished a vaccine project costing 144,300 USD between 2016 and 2019 (see Table 3).

Table 3. Research related to the platform for an immunological response to viral infection and vaccine development (Sub-Cluster 1-2).

\begin{tabular}{|c|c|c|c|c|c|c|c|}
\hline NO & Organization & Title & $\begin{array}{l}\text { Estimated Average } \\
\text { Cost/Fiscal Year } \\
\text { (USD) }\end{array}$ & $\begin{array}{l}\text { Estimated } \\
\text { Total Cost } \\
\text { (USD) }\end{array}$ & Start Date & End Date & $\begin{array}{l}\text { Geographic } \\
\text { Region }\end{array}$ \\
\hline 1 & $\begin{array}{l}\text { University of North } \\
\text { Carolina Chapel Hill }\end{array}$ & $\begin{array}{l}\text { Systems immunogenetics of } \\
\text { biodefense and emerging } \\
\text { pathogens in the } \\
\text { collaborative cross }\end{array}$ & $2,437,629$ & $24,376,290$ & 5 August 2012 & 31 August 2022 & US \\
\hline 2 & $\begin{array}{l}\text { New York Blood } \\
\text { Center }\end{array}$ & $\begin{array}{c}\text { Structure-based design of } \\
\text { coronavirus subunit vaccines }\end{array}$ & 911,083 & $4,555,415$ & 21 May 2018 & 30 April 2023 & US \\
\hline 3 & $\begin{array}{c}\text { Planet } \\
\text { Biotechnology Inc }\end{array}$ & A MERS-CoV receptor decoy & 600,081 & $2,400,324$ & 1 June 2014 & 31 January 2018 & US \\
\hline 4 & $\begin{array}{l}\text { University of } \\
\text { Pennsylvania }\end{array}$ & $\begin{array}{l}\text { Murine coronavirus } \\
\text { neurovirulence role of type i } \\
\text { interferon response }\end{array}$ & 341,731 & $2,392,117$ & 1 September 2012 & 31 May 2019 & US \\
\hline 5 & $\begin{array}{l}\text { National Institute of } \\
\text { Infectious Diseases }\end{array}$ & $\begin{array}{l}\text { The development of a new } \\
\text { vaccine against human } \\
\text { coronavirus that causes } \\
\text { severe pneumonia }\end{array}$ & 48,100 & 144,300 & 1 April 2016 & 31 March 2019 & JP \\
\hline
\end{tabular}

Thirdly, the platform for the detection and point-of-care diagnostics (Sub-Cluster 1-3) is comprised of 16 projects, which are worth 34,526,645 USD. In the US, Columbia University Health Sciences completed a 5 million USD project entitled "Diagnostic and prognostic biomarkers for severe viral lung disease" between 2014 and 2019. Meanwhile, Erasmus Universitair Medisch Centrum Rotterdam in the EU worked on a study between 2014 and 2016 entitled "Early detection of emerging viruses by next generation in situ hybridization" with a budget of 205,891 USD. Between 2015 and 2018, Nihon University of Japan completed its study "Establishment of gene diagnosis of feline infectious peritonitis by the analysis of the viral genome" with expenditures of 132,600 USD (see Table 4). 
Table 4. The platform for detection and point-of-care diagnostics (Sub-Cluster 1-3).

\begin{tabular}{|c|c|c|c|c|c|c|c|}
\hline NO & Organization & Title & $\begin{array}{l}\text { Estimated Average } \\
\text { Cost/Fiscal Year } \\
\text { (USD) }\end{array}$ & $\begin{array}{l}\text { Estimated } \\
\text { Total Cost } \\
\text { (USD) }\end{array}$ & Start Date & End Date & $\begin{array}{l}\text { Geographic } \\
\text { Region }\end{array}$ \\
\hline 1 & $\begin{array}{l}\text { Columbia University } \\
\text { Health Sciences }\end{array}$ & $\begin{array}{c}\text { Diagnostic and prognostic } \\
\text { biomarkers for severe viral } \\
\text { lung disease }\end{array}$ & $1,131,261$ & $5,656,305$ & 7 March 2014 & 28 February 2019 & US \\
\hline 2 & Boston College & $\begin{array}{l}\text { New genetic tools for } \\
\text { comparative analysis of } \\
\text { emerging viruses and virus } \\
\text { host molecular interactions in } \\
\text { reservoir hosts versus } \\
\text { spillover hosts }\end{array}$ & 313,000 & 626,000 & 1 April 2018 & 30 September 2019 & US \\
\hline 3 & $\begin{array}{c}\text { Crosslife } \\
\text { Technologies Inc. }\end{array}$ & $\begin{array}{l}\text { SBIR phase 1: rapid } \\
\text { instrument-free nucleic acid } \\
\text { test for pathogens and } \\
\text { biothreats }\end{array}$ & 224,929 & 224,929 & 1 June 2017 & 31 May 2018 & US \\
\hline 4 & $\begin{array}{l}\text { Erasmus Universitair } \\
\text { Medisch Centrum } \\
\text { Rotterdam }\end{array}$ & $\begin{array}{l}\text { Early detection of emerging } \\
\text { viruses by next generation in } \\
\text { situ hybridization }\end{array}$ & 102,946 & 205,891 & 1 July 2014 & 30 June 2016 & EU \\
\hline 5 & Nihon University & $\begin{array}{c}\text { Establishment of gene } \\
\text { diagnosis of feline infectious } \\
\text { peritonitis by the analysis of } \\
\text { the viral genome }\end{array}$ & 44,200 & 132,600 & 1 April 2015 & 31 March 2018 & JP \\
\hline
\end{tabular}

3.1.2. Research on the Virus Protein Structure, Activity/Function-Based Antivirus Therapeutics (Treatment) Design, and Activity/Resistance Modulation (Cluster 2)

Overall, research on the virus protein structure, activity/function-based antivirus therapeutics (treatment) design, and activity/resistance modulation (Cluster 2) was comprised of 37 projects worth $83,537,310$ USD.

First, structure-activity relationship modeling-based virus prediction and activity modulation (Sub-Cluster 2-1) included six projects totaling 6,911,261 USD. In the US, The Blood Systems Research Institute joined a 2 million USD project, "Modeling viral entry and its inhibition using SARS-CoV", between 2007 and 2012. Harvard University worked on a study between 2013 and 2016 entitled "Structure and mechanism of programmed ribosomal frameshifting in SARS coronavirus". In the EU, Katholieke Universiteit Leuven completed a 3.5 million USD project, entitled "Virus discovery and epidemic tracing from high throughput metagenomic sequencing", between 2015 and 2018. Meanwhile, Osaka University of Japan studied the same research area with expenditures of 144,300 USD between 2016 and 2019 (See Table 5).

Table 5. Structure-activity relationship modeling-based virus prediction and activity modulation (Sub-Cluster 2-1).

\begin{tabular}{|c|c|c|c|c|c|c|c|}
\hline NO & Organization & Title & $\begin{array}{l}\text { Estimated Average } \\
\text { Cost/Fiscal Year } \\
\text { (USD) }\end{array}$ & $\begin{array}{l}\text { Estimated } \\
\text { Total Cost } \\
\text { (USD) }\end{array}$ & Start Date & End Date & $\begin{array}{l}\text { Geographic } \\
\text { Region }\end{array}$ \\
\hline 1 & $\begin{array}{c}\text { Blood Systems } \\
\text { Research Institute }\end{array}$ & $\begin{array}{l}\text { Modeling viral entry and its } \\
\text { inhibition using SARS-CoV }\end{array}$ & 406,843 & $2,034,215$ & 15 December 2007 & 30 November 2012 & US \\
\hline 2 & Harvard University & $\begin{array}{c}\text { Structure and mechanism of } \\
\text { programmed ribosomal } \\
\text { frameshifting in SARS } \\
\text { coronavirus }\end{array}$ & 375,687 & $1,127,061$ & 7 February 2013 & 31 January 2016 & US \\
\hline 3 & $\begin{array}{c}\text { Katholieke } \\
\text { Universiteit Leuven }\end{array}$ & $\begin{array}{l}\text { Virus discovery and epidemic } \\
\text { tracing from high throughput } \\
\text { metagenomic sequencing }\end{array}$ & $1,168,428$ & $3,505,285$ & 1 June 2015 & 31 May 2018 & EU \\
\hline 4 & Osaka University & $\begin{array}{c}\text { Elucidation of the } \\
\text { establishment and the } \\
\text { virulence factors of reverse } \\
\text { genetic manipulation system } \\
\text { of MERS coronavirus }\end{array}$ & 48,100 & 144,300 & 1 April 2016 & 31 March 2019 & JP \\
\hline 5 & Yamaguchi University & $\begin{array}{l}\text { Analysis of coronavirus } \\
\text { evolution mechanism for } \\
\text { appearance prediction } \\
\text { emerging coronavirus }\end{array}$ & 21,700 & 43,400 & 24 April 2015 & 31 March 2017 & JP \\
\hline
\end{tabular}

Secondly, studies on the design of antiviral agents based on the structure and function of viral and human receptor proteins (Sub-Cluster 2-2) included 31 projects totaling 76,626,049 USD. In the US, 
The University of North Carolina Chapel Hill and Kansas State University committed to spending 6.5 million USD on a project named "Broad-spectrum antiviral GS-5734 to treat MERS-CoV and related emerging CoV" between 2017 and 2022, and to 3.8 million USD worth of a project entitled "Small molecule protease inhibitors against MERS-CoV" between 2018 and 2023. In Japan, the Nippon Veterinary and Life Science University finished "The development of specific anticoronavirus drugs using the novel glycosidase inhibitors", spending 144,000 USD between 2016 and 2019 (see Table 6).

Table 6. Studies on the design of antiviral agents based on the structure and function of viral and human receptor proteins (Sub-Cluster 2-2).

\begin{tabular}{|c|c|c|c|c|c|c|c|}
\hline NO & Organization & Title & $\begin{array}{l}\text { Estimated Average } \\
\text { Cost/Fiscal Year } \\
\text { (USD) }\end{array}$ & $\begin{array}{l}\text { Estimated } \\
\text { Total Cost } \\
\text { (USD) }\end{array}$ & Start Date & End Date & $\begin{array}{l}\text { Geographic } \\
\text { Region }\end{array}$ \\
\hline 1 & $\begin{array}{l}\text { University of North } \\
\text { Carolina Chapel Hill }\end{array}$ & $\begin{array}{l}\text { Broad-spectrum antiviral } \\
\text { GS-5734 to treat MERS-CoV } \\
\text { and related emerging CoV }\end{array}$ & $1,310,955$ & $6,554,775$ & 9 August 2017 & 31 July 2022 & US \\
\hline 2 & $\begin{array}{l}\text { University of } \\
\text { Alabama at } \\
\text { Birmingham }\end{array}$ & $\begin{array}{l}\text { Inhibitors of coronavirus } \\
\text { fidelity and cap methylation } \\
\text { as broadly applicable }\end{array}$ & 996,397 & $4,981,985$ & 1 March 2014 & 28 February 2019 & US \\
\hline 3 & $\begin{array}{l}\text { Kansas State } \\
\text { University }\end{array}$ & $\begin{array}{c}\text { Small molecule protease } \\
\text { inhibitors against MERS-CoV }\end{array}$ & 775,916 & $3,879,580$ & 15 May 2018 & 30 April 2023 & US \\
\hline 4 & $\begin{array}{l}\text { The Johns Hopkins } \\
\text { University }\end{array}$ & $\begin{array}{l}\text { Applying human factors and } \\
\text { mathematical modeling } \\
\text { approaches to prevent } \\
\text { transmission of high } \\
\text { consequence pathogens }\end{array}$ & $1,222,700$ & $3,668,100$ & 30 September 2015 & 29 September 2018 & US \\
\hline 5 & $\begin{array}{l}\text { Nippon Veterinary } \\
\text { and Life Science } \\
\text { University }\end{array}$ & $\begin{array}{l}\text { The development of specific } \\
\text { anti coronavirus drugs using } \\
\text { the novel } \\
\text { glycosidase inhibitors }\end{array}$ & 48,100 & 144,300 & 1 April 2016 & 31 March 2019 & JP \\
\hline
\end{tabular}

3.1.3. Infectious Disease Epidemiological Investigation and Animal and Environmental Ecology (Cluster 3)

Infectious disease epidemiological investigation and animal and environmental ecology (Cluster 3) contained 25 projects worth 152,373,487 USD. In 2018, George Washington University in the US began executing a project worth 9.9 million USD titled "Ecology of MERS-CoV in camels, humans, and wildlife in Ethiopia". It will be completed in 2022. In the EU, Erasmus Universitair Medisch Centrum Rotterdam committed to an 18 million USD project entitled "Anticipating the global onset of novel epidemics" between 2018 and 2023. In Japan, the National Institute of Infectious Diseases recently completed "The survey of middle east respiratory syndrome coronavirus of the dromedary in Ethiopia" project with total expenditures of 413,400 USD between 2017 and 2020 (see Table 7).

Table 7. Infectious Disease Epidemiological Investigation and Animal and Environmental Ecology (Cluster 3).

\begin{tabular}{|c|c|c|c|c|c|c|c|}
\hline NO & Organization & Title & $\begin{array}{l}\text { Estimated Average } \\
\text { Cost/Fiscal Year } \\
\text { (USD) }\end{array}$ & $\begin{array}{l}\text { Estimated } \\
\text { Total Cost } \\
\text { (USD) }\end{array}$ & Start Date & End Date & $\begin{array}{l}\text { Geographic } \\
\text { Region }\end{array}$ \\
\hline 1 & $\begin{array}{l}\text { George Washington } \\
\text { University }\end{array}$ & $\begin{array}{l}\text { Ecology of MERS-CoV in } \\
\text { camels, humans, and wildlife } \\
\text { in Ethiopia }\end{array}$ & $2,487,071$ & $9,948,284$ & 1 September 2018 & 31 August 2022 & US \\
\hline 2 & $\begin{array}{c}\text { Montana State } \\
\text { University-Bozeman }\end{array}$ & $\begin{array}{l}\text { Dynamics of zoonotic } \\
\text { systems: human-bat- } \\
\text { pathogen interactions }\end{array}$ & $1,650,000$ & $6,600,000$ & 1 September 2017 & 31 August 2021 & US \\
\hline 3 & $\begin{array}{l}\text { Fred Hutchinson } \\
\text { Cancer Research } \\
\text { Center }\end{array}$ & $\begin{array}{l}\text { Realtime tracking of virus } \\
\text { evolution for vaccine strain } \\
\text { selection and } \\
\text { epidemiological investigation }\end{array}$ & 409,400 & $2,047,000$ & 23 August 2016 & 31 May 2021 & US \\
\hline 4 & $\begin{array}{l}\text { Erasmus Universitair } \\
\text { Medisch Centrum } \\
\text { Rotterdam }\end{array}$ & $\begin{array}{l}\text { Anticipating the global onset } \\
\text { of novel epidemics }\end{array}$ & $3,670,585$ & $18,352,925$ & 1 November 2011 & 31 October 2016 & EU \\
\hline 5 & $\begin{array}{l}\text { National Institute of } \\
\text { Infectious Diseases }\end{array}$ & $\begin{array}{l}\text { The survey of middle east } \\
\text { respiratory syndrome } \\
\text { coronavirus of the } \\
\text { dromedary in Ethiopia }\end{array}$ & 137,800 & 413,400 & 1 April 2017 & 31 March 2020 & JP \\
\hline
\end{tabular}




\subsection{Research and Development Fields of Coronavirus-Related National Funded Projects of Korea}

3.2.1. Research on the Molecular Characteristics of Infectious Viruses and the Interaction Mechanisms of Viral Pathogens and Human Hosts, Including the Immune Response, for Developing Diagnostics, Therapeutics, and a Vaccine against COVID-19 in Korea (Cluster 1)

Overall, research on the molecular characteristics of infectious viruses and the interaction mechanisms of viral pathogens and human hosts, including immune responses, for developing diagnostics, therapeutics, and a vaccines against COVID-19 in Korea (Cluster 1) was comprised of 121 projects worth $64,518,268$ USD.

Firstly, research related to the mechanisms of infection, the life cycle of SARS-CoV-2, and the identification of a virus-host interaction mechanism in Korea (Sub-Cluster 1-1) consisted of 34 projects, totaling 4,351,252 USD. Kookmin University's project, "Reaction mechanism study on SARS Coronavirus helicase and its applications to develop the inhibitors" spent 137,209 USD between 2013 and 2016. Chonbuk National University and Chungnam National University have participated in the same research areas. Chonbuk National University's "A genetic characteristic study for zoonotic potential of several pathogens from bats in Korea" has expected expenditures 45,455 USD. The study began in 2018 and will end in 2021. Chungnam National University's project, "Identification of the mechanism of coronavirus cross-species transmission and pathogenesis mediated by host proteases" has expected expenditures of 136,364 USD between 2020 and 2023 (see Table 8).

Table 8. Research related to the mechanisms of infection, the life cycle of SARS-CoV-2, and the identification of a virus-host interaction mechanism in Korea (Sub-Cluster 1-1).

\begin{tabular}{|c|c|c|c|c|c|c|}
\hline NO & Organization & Title & $\begin{array}{l}\text { Estimated Average } \\
\text { Cost/Fiscal Year } \\
\text { (USD) }\end{array}$ & $\begin{array}{l}\text { Estimated } \\
\text { Total Cost } \\
\text { (USD) }\end{array}$ & Start Date & End Date \\
\hline 1 & Kookmin University & $\begin{array}{l}\text { Reaction mechanism study on } \\
\text { SARS Coronavirus helicase and } \\
\text { its applications to develop } \\
\text { the inhibitors }\end{array}$ & 45,736 & 137,209 & 1 November 2013 & 31 October 2016 \\
\hline 2 & $\begin{array}{l}\text { Chonbuk National } \\
\text { University }\end{array}$ & $\begin{array}{l}\text { A genetic characteristic study } \\
\text { for zoonotic potential of several } \\
\text { pathogens from bats in Korea }\end{array}$ & 15,152 & 45,455 & 1 June 2018 & 31 May 2021 \\
\hline 3 & Kookmin University & $\begin{array}{l}\text { Mechanistic study on SARS } \\
\text { Coronavirus helicase in the } \\
\text { process of viral } \\
\text { genome replication }\end{array}$ & 18,272 & 54,816 & 1 September 2010 & 31 August 2013 \\
\hline 4 & $\begin{array}{c}\text { Chungnam National } \\
\text { University }\end{array}$ & $\begin{array}{l}\text { Identification of mechanism of } \\
\text { coronavirus cross-species } \\
\text { transmission and pathogenesis } \\
\text { mediated by host proteases }\end{array}$ & 45,455 & 136,364 & 1 March 2020 & 28 February 2023 \\
\hline 5 & Center for Disease Control & $\begin{array}{l}\text { Immunogenocity of SARS-CoV } \\
\text { receptor binding protein } \\
\text { expressed on } \\
\text { coxsackieviral vector }\end{array}$ & 30,455 & 60,909 & 1 January 2010 & 31 December 2011 \\
\hline
\end{tabular}

Secondly, research related to the platform for the immunological response to viral infection and for vaccine development in Korea (Sub-Cluster 1-2) is composed of 39 projects worth 37,045,703 USD. Seoul National University has concentrated their project on "The development of therapeutic antibodies against Middle Eastern respiratory syndrome coronavirus and Zika virus" with spending totaling near 500,000 USD between 2016 and 2021. The International Vaccine Research Institute completed their project, "Discovery of MERS-CoV vaccine Candidate and Evaluation of Vaccine efficacy using in vitro system", having spent 318,182 USD between 2015 and 2019 (see Table 9). 
Table 9. Research related to the platform for the immunological response to viral infection and for vaccine development in Korea (Sub-Cluster 1-2).

\begin{tabular}{|c|c|c|c|c|c|c|}
\hline NO & Organization & Title & $\begin{array}{l}\text { Estimated Average } \\
\text { Cost/Fiscal Year } \\
\text { (USD) }\end{array}$ & $\begin{array}{l}\text { Estimated } \\
\text { Total Cost } \\
\text { (USD) }\end{array}$ & Start Date & End Date \\
\hline 1 & Seoul National University & $\begin{array}{l}\text { The development of } \\
\text { therapeutic antibodies against } \\
\text { Middle East respiratory } \\
\text { syndrome coronavirus and } \\
\text { Zika virus }\end{array}$ & 99,273 & 496,364 & 1 July 2016 & 31 March 2021 \\
\hline 2 & $\begin{array}{l}\text { International Vaccine } \\
\text { Research Institute }\end{array}$ & $\begin{array}{l}\text { Discovery of MERS-CoV } \\
\text { vaccine Candidate and } \\
\text { Evaluation of Vaccine efficacy } \\
\text { using in vitro system }\end{array}$ & 79,545 & 318,182 & 3 December 2015 & 30 November 2019 \\
\hline 3 & Korea University & $\begin{array}{l}\text { Development of } \\
\text { next-generation universal } \\
\text { vaccine to control viral } \\
\text { infectious diseases }\end{array}$ & 181,818 & 181,818 & 1 December 2015 & 30 November 2016 \\
\hline 4 & Center for Disease Control & $\begin{array}{c}\text { Expression and } \\
\text { immunogenicity study of } \\
\text { Coxsackievirus vector of } \\
\text { SARS-CoV receptor } \\
\text { binding protein }\end{array}$ & 28,788 & 86,364 & 1 January 2008 & 31 December 2010 \\
\hline 5 & $\begin{array}{l}\text { Chonbuk National } \\
\text { University }\end{array}$ & $\begin{array}{l}\text { Development of standard } \\
\text { protocol for measuring the } \\
\text { amount of vaccine candidate } \\
\text { and the titer of antibody for } \\
\text { MERS-CoV(2) }\end{array}$ & 22,727 & 45,455 & 16 February 2016 & 30 November 2017 \\
\hline
\end{tabular}

Thirdly, the platform for detection and point-of-care diagnostics in Korea (Sub-Cluster 1-3) is composed of 45 projects totaling 23,872,321 USD. Chonbuk National University started conducting their project "The development of prompt and customized genetic engineering technology-based approaches for the control of disastrous infectious diseases" in 2017, which is expected to finish in 2026 with total expenditures of 477,328 USD. Meanwhile, The Korea Research Institute of Bioscience and Biotechnology's project "Next-generation virus detection and control technology development" has a budget of 87,273 USD between 2019 and 2023. In the for-profit sector, Seoul's Asan Hospital has dedicated 153,182 USD towards their project, "Advancement of specimen processing and evaluation of ultrasensitive diagnostic platform technologies for emerging viruses" between 2016 and 2021 (see Table 10).

Table 10. The platform for detection and point-of-care diagnostics in Korea (Sub-Cluster 1-3).

\begin{tabular}{|c|c|c|c|c|c|c|}
\hline NO & Organization & Title & $\begin{array}{l}\text { Estimated Average } \\
\text { Cost/Fiscal Year } \\
\text { (USD) }\end{array}$ & $\begin{array}{l}\text { Estimated } \\
\text { Total Cost } \\
\text { (USD) }\end{array}$ & Start Date & End Date \\
\hline 1 & $\begin{array}{l}\text { Chonbuk National } \\
\text { University }\end{array}$ & $\begin{array}{l}\text { The development of prompt } \\
\text { and customized genetic } \\
\text { engineering technology-based } \\
\text { approaches for the control of } \\
\text { disastrous infectious diseases }\end{array}$ & 53,036 & 477,328 & 1 June 2017 & 28 February 2026 \\
\hline 2 & Konkuk University & $\begin{array}{l}\text { Development of platform } \\
\text { technology for highly sensitive } \\
\text { detection of emerging viruses } \\
\text { using gene amplification and } \\
\text { fluorescence monitoring }\end{array}$ & 48,182 & 240,909 & 1 July 2016 & 31 March 2021 \\
\hline 3 & Seoul Asan Hospital & $\begin{array}{l}\text { Advancement of Specimen } \\
\text { Processing and Evaluation of } \\
\text { Ultrasensitive Diagnostic } \\
\text { Platform Technologies for } \\
\text { Emerging Viruses }\end{array}$ & 30,636 & 153,182 & 1 July 2016 & 31 March 2021 \\
\hline 4 & $\begin{array}{c}\text { Korea Research Institute of } \\
\text { Bioscience and } \\
\text { Biotechnology }\end{array}$ & $\begin{array}{l}\text { Next-generation virus } \\
\text { detection and control } \\
\text { technology development }\end{array}$ & 17,455 & 87,273 & 1 January 2019 & 31 December 2023 \\
\hline 5 & Center for Disease Control & $\begin{array}{l}\text { Development of diagnostic } \\
\text { resources for the rapid response } \\
\text { of emerging respiratory viruses }\end{array}$ & 181,818 & 545,455 & 1 January 2016 & 31 December 2018 \\
\hline
\end{tabular}


3.2.2. Research on the Virus Protein Structure, Activity/Function-Based Antivirus Therapeutics (Treatment) Design, and Activity/Resistance Modulation in Korea (Cluster 2)

Overall, research on the virus protein structure, activity/function-based antivirus therapeutics (treatment) design, and activity/resistance modulation in Korea (Cluster 2) consisted of 32 projects, totaling 14,451,688 USD.

Firstly, structure-activity relationship modeling-based virus prediction and activity modulation in Korea (Sub-Cluster 2-1) is composed of seven projects, worth 2,775,533 USD. The Korea Research Institute of Bioscience and Biotechnology has committed to funding a project entitled "Development of viral recombination prediction and validation technique using bioinformatics" with projected expenditures of 272,727 USD, which started in 2014 and is projected to finish in 2022. Yonsei University's "Basic research on new drug candidate discovery based on chemo-informatics" project spent 890,909 USD between 2006 and 2009. Meanwhile, Kyungdon University's project, "Big-data analysis on viral infection using epigenetic information", spent 144,475 USD between 2016 and 2019 (see Table 11).

Table 11. Structure-activity relationship modeling-based virus prediction and activity modulation in Korea (Sub-Cluster 2-1).

\begin{tabular}{|c|c|c|c|c|c|c|}
\hline NO & Organization & Title & $\begin{array}{l}\text { Estimated Average } \\
\text { Cost/Fiscal Year } \\
\text { (USD) }\end{array}$ & $\begin{array}{l}\text { Estimated } \\
\text { Total Cost } \\
\text { (USD) }\end{array}$ & Start Date & End Date \\
\hline 1 & $\begin{array}{c}\text { Korea Research Institute of } \\
\text { Bioscience and } \\
\text { Biotechnology }\end{array}$ & $\begin{array}{l}\text { Development of viral } \\
\text { recombination prediction and } \\
\text { validation technique using } \\
\text { bioinformatics }\end{array}$ & 30,303 & 272,727 & 1 January 2014 & 31 August 2022 \\
\hline 2 & Yonsei University & $\begin{array}{l}\text { Basic research on new drug } \\
\text { candidate discovery based on } \\
\text { chemo-informatics }\end{array}$ & 296,970 & 890,909 & 1 September 2006 & 31 August 2009 \\
\hline 3 & Seoul National University & $\begin{array}{l}\text { Simulation study for the } \\
\text { prediction of zoonotic infection } \\
\text { risk using genetic variation } \\
\text { markers of viruses }\end{array}$ & 26,515 & 79,545 & 1 June 2017 & 31 May 2020 \\
\hline 4 & Kyungdong University & $\begin{array}{l}\text { Big-data analysis on viral } \\
\text { infection using epigenetic } \\
\text { information }\end{array}$ & 48,158 & 144,475 & 1 June 2016 & 31 May 2019 \\
\hline 5 & Center for Disease Control & $\begin{array}{l}\text { Variation predict and viral } \\
\text { attenuation of MERS-CoV }\end{array}$ & 254,545 & 763,636 & 1 January 2016 & 31 December 2018 \\
\hline
\end{tabular}

Secondly, studies on the design of antiviral agents based on the structure and function of viral and human receptor proteins in Korea (Sub-Cluster 2-2) were composed of 25 projects worth 11,676,155 USD. Institut Pasteur Korea has pledged to spend 3 million USD on the project entitled "Preparedness of emerging viruses" between 2017 and 2022. Ilyang Pharmaceutical Co., Ltd. and Hallym University also have concentrated on a similar project, "Deriving new candidates for the development of therapeutics in the Middle East Respiratory Syndrome", with budgeted expenditures of 763,636 and "Development therapeutic target and candidate for immunotherapy against middle east respiratory syndrome coronavirus (MERS-CoV)" with a budget of 418,182 USD between 2016 and 2021, respectively (see Table 12). 
Table 12. Studies on the design of antiviral agents based on the structure and function of viral and human receptor proteins in Korea (Sub-Cluster 2-2).

\begin{tabular}{|c|c|c|c|c|c|c|}
\hline NO & Organization & Title & $\begin{array}{l}\text { Estimated Average } \\
\text { Cost/Fiscal Year } \\
\text { (USD) }\end{array}$ & $\begin{array}{l}\text { Estimated } \\
\text { Total Cost } \\
\text { (USD) }\end{array}$ & Start Date & End Date \\
\hline 1 & Institut Pasteur Korea & $\begin{array}{c}\text { Preparedness of Emerging } \\
\text { Viruses }\end{array}$ & 500,035 & $3,000,210$ & 30 June 2017 & 31 December 2022 \\
\hline 2 & $\begin{array}{c}\text { Ilyang Pharmaceutical } \\
\text { Co., Ltd. }\end{array}$ & $\begin{array}{l}\text { Deriving new candidates for } \\
\text { the development of } \\
\text { therapeutics in the Middle East } \\
\text { Respiratory Syndrome }\end{array}$ & 152,727 & 763,636 & 1 July 2016 & 31 March 2021 \\
\hline 3 & Hallym University & $\begin{array}{l}\text { Development of therapeutic } \\
\text { target and candidate for } \\
\text { immunotherapy against middle } \\
\text { east respiratory syndrome } \\
\text { coronavirus (MERS-CoV) }\end{array}$ & 83,636 & 418,182 & 1 July 2016 & 31 March 2021 \\
\hline 4 & $\begin{array}{l}\text { Korea Advanced Institute } \\
\text { of Science and Technology }\end{array}$ & $\begin{array}{l}\text { Development of novel } \\
\text { therapeutics for infectious } \\
\text { diseases through activation of } \\
\text { innate immune system }\end{array}$ & 178,182 & 356,364 & 1 November 2015 & 31 October 2017 \\
\hline 5 & $\begin{array}{l}\text { Chonbuk National } \\
\text { University }\end{array}$ & $\begin{array}{l}\text { Development of recombinant } \\
\text { subunit vaccine candidates for } \\
\text { the protection against } \\
\text { MERS-CoV infection }\end{array}$ & 68,182 & 272,727 & 3 December 2015 & 30 November 2019 \\
\hline
\end{tabular}

3.2.3. Infectious Disease Epidemiological Investigation and Animal and Environmental Ecology in Korea (Cluster 3)

Infectious disease epidemiological investigation and animal and environmental ecology in Korea (Cluster 3) contained 12 projects worth 2,589,259 USD. Seoul City University is executing a 227,273 USD project entitled "Studies on the Development of MERS Diffusion Route Detection and Prevention Technology", which started in 2019 and is expected to be completed by 2024. Meanwhile, the National Medical Center finished "A Four year follow-up clinical and immunological study of MERS patients" project worth 181,816 USD (see Table 13).

Table 13. Infectious disease epidemiological investigation and animal and environmental ecology in Korea (Cluster 3).

\begin{tabular}{|c|c|c|c|c|c|c|}
\hline NO & Organization & Title & $\begin{array}{l}\text { Estimated Average } \\
\text { Cost/Fiscal Year } \\
\text { (USD) }\end{array}$ & $\begin{array}{l}\text { Estimated } \\
\text { Total Cost } \\
\text { (USD) }\end{array}$ & Start Date & End Date \\
\hline 1 & Seoul City University & $\begin{array}{l}\text { Studies on the Development of } \\
\text { MERS Diffusion Route } \\
\text { Detection and Prevention } \\
\text { Technology: focus on public } \\
\text { transportation users }\end{array}$ & 45,455 & 227,273 & 29 November 2019 & 28 November 2024 \\
\hline 2 & Inha University & $\begin{array}{l}\text { Mathematical Control } \\
\text { Strategies for Effective } \\
\text { Preventive Measures Against } \\
\text { Epidemics: Macroscopic and } \\
\text { Microscopic Viewpoints }\end{array}$ & 26,515 & 79,545 & 1 June 2017 & 31 May 2020 \\
\hline 3 & Konkuk University & $\begin{array}{l}\text { Mathematical models of } \\
\text { contact management and } \\
\text { spread of infectious diseases }\end{array}$ & 90,909 & 181,818 & 7 November 2018 & 31 December 2019 \\
\hline 4 & $\begin{array}{c}\text { The National Medical } \\
\text { Center }\end{array}$ & $\begin{array}{l}\text { A Four year follow-up clinical } \\
\text { and immunological study of } \\
\text { MERS patients }\end{array}$ & 181,816 & 181,816 & 1 February 2019 & 31 December 2019 \\
\hline 5 & $\begin{array}{l}\text { Woori Airtech Korea } \\
\text { Co., Ltd. }\end{array}$ & $\begin{array}{l}\text { Developed mobile sound } \\
\text { pressure booths to prevent } \\
\text { secondary infections and } \\
\text { medical staff when treating } \\
\text { various infectious diseases such } \\
\text { as MERS }\end{array}$ & 58,237 & 58,237 & 1 June 2016 & 28 February 2017 \\
\hline
\end{tabular}

\subsection{Comparison between the Developed Nations and Korea}

Due to the differences in the absolute amount of R\&D funding per nation, ratio analysis was undertaken to compare the relative magnitudes of these coronavirus-related $R \& D$ areas among nations, which allowed for the identification of these nations' strengths and weaknesses [32]. 
The US has a wide range of research fields for infectious disease preparedness ranging from basic research (i.e., the identification and mechanism of the viral pathogen) $(62.0 \%)$ to animal-environmental ecology and the epidemiologic investigation and quarantine of infectious diseases $(23.8 \%)$ and has invested from a mid- to long-term perspective (see Figure 3). Although the funding scale for coronavirus-related R\&D areas in the EU and Japan is smaller than that of the United States, the directions for the R\&D areas are considerably analogous to those in the US. These trends in coronavirus-related R\&D funding show that the directions for the R\&D investment are in accordance with the "One Health" concept of the WHO, which is a global strategy for all aspects of healthcare for the environment-animal-human paradigm [33].

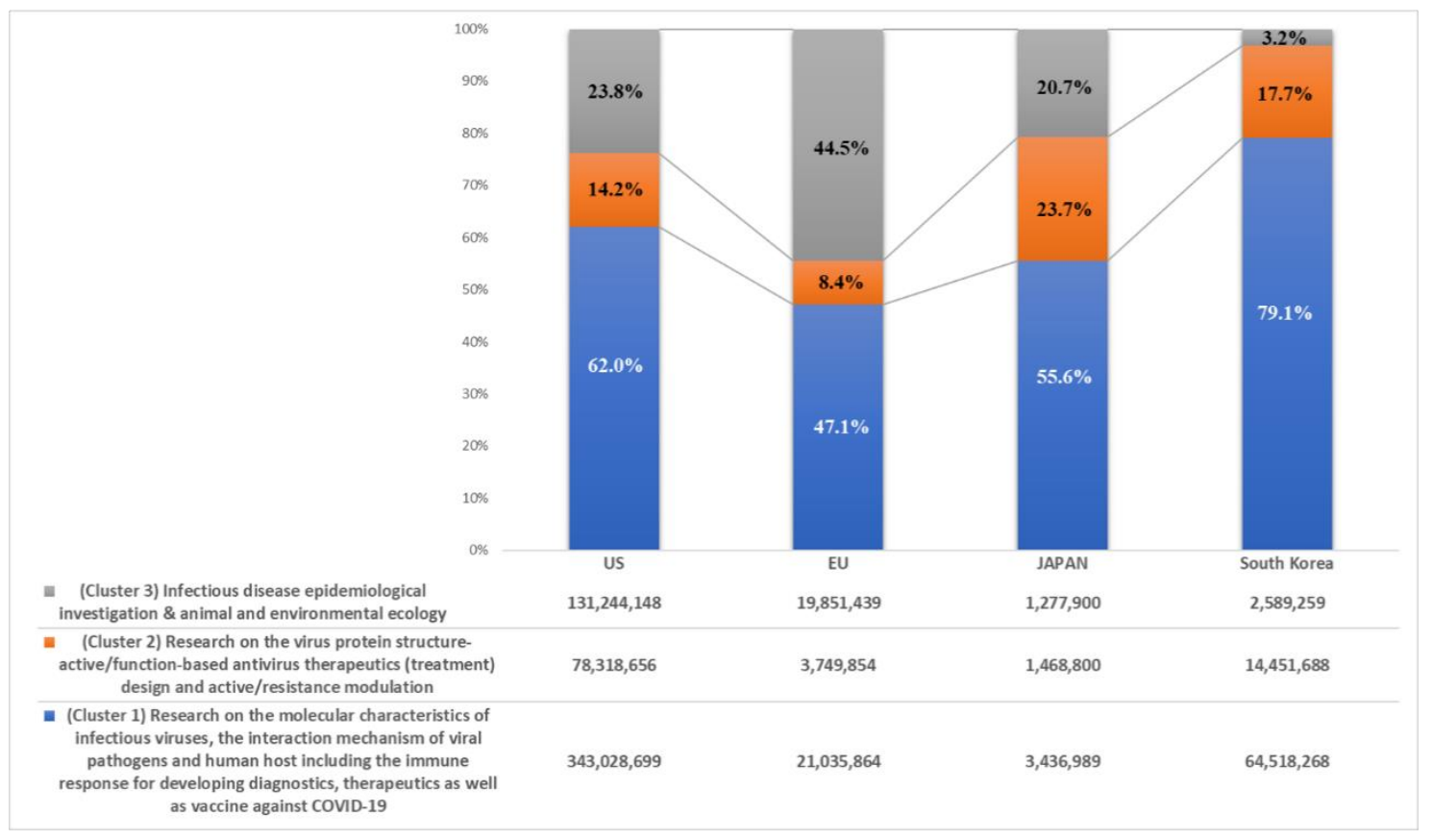

Figure 3. Comparative ratio analysis for three coronavirus-related R\&D areas among the US, the EU, Japan, and Korea.

The Korean government has invested in coronavirus-related basic research and core technologies (Sub-Cluster 1-1: 4.4\%, Sub-Cluster 1-2: 45.4\%, and Sub-Cluster 1-3: 29.3\%), including the identification of infectious disease pathogens, the structure and replication mechanism of viruses, infection mechanisms in the host, and immune responses, which are dominated by the US and EU's technological edge. However, some coronavirus-related R\&D areas were heavily supported by the Korean government compared to the US. These R\&D areas covered research related to the platform for the immunological response to viral infections and for vaccine development (Sub-Cluster 1-2: Korea: $45.4 \%$ vs. the US: $26.3 \%$ ), the platform for detection and point-of-care diagnostics (Sub-Cluster 1-3: Korea: $29.3 \%$ vs. the US: $6.1 \%$ ), and the studies on the design of antiviral agents based on the structure and function of viral and human receptor proteins (Sub-Cluster 2-2: Korea: $14.3 \%$ vs. the US: $13.6 \%$ ), which are not only highly applied in clinical settings in practice but also have high possibilities for technological commercialization from a short- or medium-term perspective (see Figure 4). The characteristics of Korea's R\&D funding may be due to the combined needs of the profit sector, which has emphasized short- or medium-term returns on investment, and the bio-industry promotion policy of the Korean government to strengthen the private sector's technological advantage. Moreover, it is reasonable to deduce that the government-driven R\&D on viruses after the spread of MERS-CoV in 2015 also had a profound impact on expenditures. 


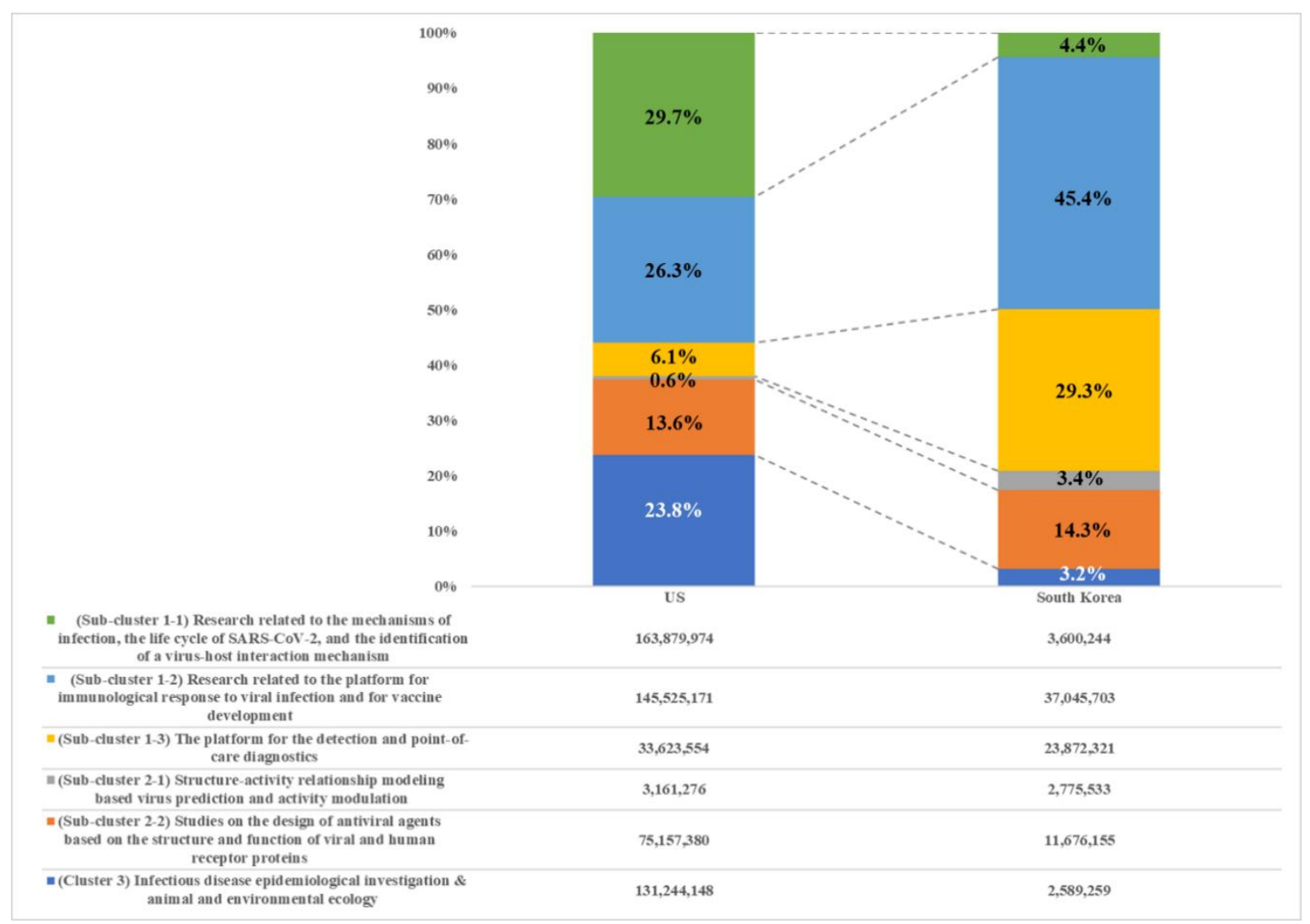

Figure 4. Comparative ratio analysis for six coronavirus-related R\&D areas for the US and Korea.

\section{Discussion}

This study aimed to elucidate the trends of coronavirus-related R\&D-because COVID-19 has been globally endangering human health and well-being since December 2019 and, at the moment, the spread of COVID-19 has barely been controlled in Korea-thereby deriving directions for government-driven $R \& D$ to prepare for the post-corona pandemic era. Three coronavirus-related $R \& D$ areas were clustered through co-occurrence matrix analysis, and then, on the subjects of two of them, five sub-clusters were additionally extrapolated based on experts' reviews. According to the results, the US, the EU, and Japan have invested in coronavirus-related research areas through 160 projects worth 1,099,242,389 USD, nine projects worth 44,637,157 USD, and 46 projects worth 6,183,689 USD, respectively. Meanwhile, Korea has funded 170 projects worth about 81,559,215 USD. Due to the centralized database of Korea, its coronavirus-related R\&D activities may be overestimated. Despite this limitation, we found that developed nations focused their propensity on investing in entire research areas. On the other hand, due to the outbreak of MERS-CoV in 2015, Korea is likely to continue pursuing technological commercialization to strengthen its bio-industry competitiveness in some specific areas rather than basic research areas from a short-and medium-term viewpoint.

\section{Conclusions}

This result has three profound implications for Korea. Firstly, the coronavirus crisis has affected the healthcare systems of Korea locally and has driven many countries around the world to their breaking points, thereby making it clear that the international collaboration of the entire R\&D network must remain a priority. Thus, the Korean government must confront the deficiency of their capabilities in core technology areas rather than the "K-quarantine" model, which was emphasized as an asset to support economic cooperation, to pioneer new markets, and to bolster the nation's reputation in the international community [34]. Secondly, it is useful for Korea to establish long-term strategies 
such as international cooperation programs in human resource exchange and bilateral/multilateral $R \& D$ activities among the leading organizations. In particular, it is necessary to develop the infectious disease-related basic research, diagnostics, vaccines, and therapeutics where Korea's technology is insufficient. Finally, basic information on the amount of R\&D funding and research organizations in leading nations may allow stakeholders in these nations to consider the future directions for establishing R\&D investments and policies in the post-corona crisis era. National funding data-based analysis could only provide financial information, which was impossible to deduce when a scientific publication- or patent-based analysis was undertaken.

As the coronavirus crisis has had devastating impacts on all social and economic sectors around the world, there is a strong need for the adequate global detection and an adequate response to the identification of new variants, including new epidemic variants or new variants with pandemic potential, by enhancing globally collaborative efforts in scientific societies. It is necessary to investigate the status quo of the R\&D of global infectious diseases in order to improve global cooperation strategies, with more effective organizational support through funding the R\&D of technologies that deal with infectious diseases. Further study is needed on the analysis of R\&D funding in virology, recognized as a basic research area for battling against infectious diseases more effectively, and its associated disciplines to strengthen the capacity of global infectious disease surveillance. It may provide useful insights for strategic approaches to an international collaboration network, thereby enhancing the assessment of international cooperative research projects and improving the capacity for a global response to infectious disease threats.

As aforementioned, the US, the EU, and Japan's data sources did not include information on the entire funding data of these nations. However, Korea's NTIS contains a centralized database for the entire data of national funding, thereby creating a "home advantage" bias. Moreover, the limitation of this study was that it was focused narrowly on coronavirus-related national funded projects. Thus, the data that were retrieved could not cover the study of other serious infectious diseases such as Zika, Ebola, and Nipah Virus.

Supplementary Materials: The following are available online at http:/www.mdpi.com/2227-9032/8/3/204/s1. Table S1: Research related to mechanisms of infection, the life cycle of SARS-CoV-2, and identification of virus-host interaction mechanism (Sub-cluster 1-1), Table S2: Researches related to platform for immunological response to viral infection and for vaccine development (Sub-cluster 1-2), Table S3: Platform for detection and point-of-care diagnostics (Sub-cluster 1-3), Table S4: Structure-activity relationship modeling based virus prediction and activity modulation (Sub-cluster 2-1), Table S5: Studies on design of antiviral agents based on the structure and function of viral and human receptor proteins in Korea (Sub-cluster 2-2), Table S6: Infectious Disease Epidemiological Investigation \& Animal and Environmental Ecology (Cluster 3), Table S7: Researches related to mechanisms of infection, the life cycle of SARS-CoV-2, and identification of virus-host interaction mechanism in Korea (Sub-cluster 1-1), Table S8: Researches related to platform for immunological response to viral infection and for vaccine development in Korea (Sub-cluster 1-2), Table S9: Platform for detection and point-of-care diagnostics in Korea (Sub-cluster 1-3), Table S10: Structure-activity relationship modeling based virus prediction and activity modulation in Korea (Sub-cluster 2-1), Table S11: Studies on design of antiviral agents based on the structure and function of viral and human receptor proteins in Korea (Sub-cluster 2-2), Table S12: Infectious Disease Epidemiological Investigation \& Animal and Environmental Ecology in Korea (Cluster 3).

Author Contributions: Conceptualization, D.L.; data curation, D.L.; formal analysis, D.L.; funding acquisition, K.K.; investigation, D.L.; methodology, Y.H.; project administration, K.K.; resources, Y.H.; software, Y.H.; supervision, K.K.; validation, K.K.; visualization, Y.H. and K.K.; writing-original draft, D.L. and K.K.; writing-review and editing, K.K. All authors have read and agreed to the published version of the manuscript.

Funding: This work was supported by the Korea Institute of Science and Technology Information (KISTI) granted by the Korean government (No. K-20-L03-C03-S01).

Conflicts of Interest: The authors declare no conflict of interest. 


\section{References}

1. Gralinski, L.E.; Menachery, V.D. Return of the coronavirus: 2019-NCoV. Viruses 2020, 12, 135. [CrossRef] [PubMed]

2. Her, M. How is COVID-19 affecting South Korea? What is our current strategy? Disaster Med. Public Health Prep. 2020. [CrossRef] [PubMed]

3. WHO. Coronavirus Disease. Available online: https://www.who.int/emergencies/diseases/novel-coronavirus2019 (accessed on 12 January 2020).

4. WHO. WHO Timeline-COVID-19. Available online: https://www.who.int/news-room/detail/27-04-2020who-timeline---covid-19 (accessed on 12 January 2020).

5. Khan, N.; Naushad, M. Effects of corona virus on the world community. SSRN Electron. J. 2020. [CrossRef]

6. Borrell, J. Policy Brief: The Post-Coronavirus World Is Already Here; European Council on Foreign Relations (ECFR): London, UK, 2020.

7. Sridhar, D.; Frenk, J.; Gostin, L.; Moon, S. Global rules for global health: Why we need an independent, impartial WHO. devi sridhar and colleagues argue that who's unique political legitimacy makes it essential to achieving international action on global health and call for governments to re-establish guaranteed core funding. BMJ 2014, 348. [CrossRef]

8. Gates, B. Responding to Covid-19-A once-in-a-century pandemic? N. Engl. J. Med. 2020, 382, 1677-1679. [CrossRef]

9. WHO. A Coordinated Global Research Roadmap: 2019 Novel Coronavirus; World Health Organization: Geneva, Switzerland, 2020.

10. Li, J.-Y.; You, Z.; Wang, Q.; Zhou, Z.-J.; Qiu, Y.; Luo, R.; Ge, X.-Y. The epidemic of 2019-Novel-Coronavirus (2019-NCoV) pneumonia and insights for emerging infectious diseases in the future. Microbes Infect. 2020, 22, 80-85. [CrossRef]

11. Peeri, N.C.; Shrestha, N.; Rahman, S.; Tan, Z.; Bibi, S.; Baghbanzadeh, M. The SARS, MERS and novel Coronavirus (COVID-19) epidemics, the newest and biggest global health threats: What lessons have we learned? Int. J. Epidemiol. 2020. [CrossRef]

12. Greene, C.J.; Burleson, S.L.; Crosby, J.C.; Heimann, M.A.; Pigott, D.C. Coronavirus disease 2019: International public health considerations. J. Am. Coll. Emerg. Physicians Open 2020, 1, 70-77. [CrossRef]

13. Matthiessen, L.; Lång, H.; Klimathianaki, M.; Hanrahan, F.; Kerstiëns, B.; Martini, A.; Draghia-Akli, R. European strategy for vaccine development against infectious diseases. Vaccine 2017, 35, A20-A23. [CrossRef]

14. Fitchett, J.R.; Head, M.G.; Cooke, M.K.; Wurie, F.B.; Atun, R. Funding infectious disease research: A systematic analysis of UK research investments by funders 1997-2010. PLoS ONE 2014, 9, e105722. [CrossRef]

15. Heo, Y.; Kang, J.; Kim, K. National scientific funding for interdisciplinary research: A comparison study of infectious diseases in the US and EU. Sustain. Switz. 2019, 11, 4120. [CrossRef]

16. Park, S.-C.; Park, Y.C. Mental health care measures in response to the 2019 novel coronavirus outbreak in Korea. Psychiatry Investig. 2020, 17, 85-86. [CrossRef] [PubMed]

17. Flattening the Curve on COVID-19. Available online: https://www.mois.go.kr/eng/bbs/type002/ commonSelectBoardArticle.do?bbsId=BBSMSTR_000000000022\&nttId=76748 (accessed on 12 January 2020).

18. Pan, X.; Ojcius, D.M.; Gao, T.; Li, Z.; Pan, C.; Pan, C. Lessons learned from the 2019-NCoV epidemic on prevention of future infectious diseases. Microbes Infect. 2020, 22, 86-91. [CrossRef] [PubMed]

19. Sweileh, W.M. Global research trends of World Health Organization's top eight emerging pathogens. Glob. Health 2017, 13, 9. [CrossRef] [PubMed]

20. Carlson, C.J. Comment from PREDICT to prevention, one pandemic later. Lancet Microbe 2020, 2, 10-11. [CrossRef]

21. How Research Funders Are Tackling Coronavirus Disruption. Available online: https://www.nature.com/ articles/d41586-020-01120-2 (accessed on 17 April 2020).

22. Meirmans, S.; Butlin, R.K.; Charmantier, A.; Engelstädter, J.; Groot, A.T.; King, K.C.; Kokko, H.; Reid, J.M.; Neiman, M. Science policies: How should science funding be allocated? an evolutionary biologists' perspective. J. Evol. Biol. 2019, 32, 754-768. [CrossRef]

23. Hoon, J.; Chan, S.; Un, C. Expert systems with applications finding research trend of convergence technology based on Korean R \& D network. Expert Syst. Appl. 2011, 38, 15159-15171. [CrossRef] 
24. Seok, J.; Kim, J.; Choi, Y.K.K.; Kim, Y. An analysis of science and technology statistics trend and utilization: A case study in Korea. Cluster Comput. 2015, 18, 783-793. [CrossRef]

25. Chung, M.Y.; Lee, K. How absorptive capacity is formed in a latecomer economy: Different roles of foreign patent and know-how licensing in Korea. World Dev. 2015, 66, 678-694. [CrossRef]

26. Criscuolo, P. The 'home advantage' effect and patent families: A comparison of OECD triadic patents, the USPTO and the EPO 1. Scientometrics 2006, 66, 23-41. [CrossRef]

27. Shim, W.; Kwon, O.-J.; Moon, Y.-H.; Kim, K.-H. Understanding the dynamic convergence phenomenon from the perspective of diversity and persistence: A cross-sector comparative analysis between the United States and South Korea. PLoS ONE 2016, 11, e0159249. [CrossRef] [PubMed]

28. van Eck, N.J.; Waltman, L. Software survey: VOSviewer, a computer program for bibliometric mapping. Scientometrics 2010, 84, 523-538. [CrossRef]

29. van Eck, N.J.; Waltman, L. Visualizing bibliometric networks. In Measuring Scholarly Impact; Springer International Publishing: Cham, Switzerland, 2014; pp. 285-320.

30. Waltman, L.; Van Eck, N.J.; Noyons, E.C.M. A unified approach to mapping and clustering of bibliometric networks. J. Informetr. 2010, 4, 629-635. [CrossRef]

31. Sedighi, M. Application of word co-occurrence analysis method in mapping of the scientific fields (case study: The field of informetrics). Libr. Rev. 2016, 65, 52-64. [CrossRef]

32. Sarngadharan, M.; Kumar, R. Financial Analysis for Management Decisions; PHI Learning Private Limited: New Delhi, India, 2011.

33. Destoumieux-garzón, D.; Mavingui, P.; Boëtsch, G.; Boissier, J.; Darriet, F.; Duboz, P.; Fritsch, C.; Giraudoux, P.; le Roux, F.; Morand, S.; et al. The one health concept: 10 years old and a long road ahead. Front. Vet. Sci. 2018, 5, 14. [CrossRef] [PubMed]

34. Korea Expands Foreign Aid, Offers 'K-Quarantine' Boost. Available online: http://www.koreaherald.com/ view.php?ud=20200427000859 (accessed on 27 April 2020).

(C) 2020 by the authors. Licensee MDPI, Basel, Switzerland. This article is an open access article distributed under the terms and conditions of the Creative Commons Attribution (CC BY) license (http://creativecommons.org/licenses/by/4.0/). 